\title{
Numerical Modelling of the Behavior of Steel-Concrete Composite Columns of Different Types of Circular Cross Section Subject to Lateral Impact
}

\author{
Khalid Abdel Naser Abdel Rahim* \\ Department of Civil Engineering, Faculty of Science and Technology, University of Coimbra, Portugal
}

Submission: July 02, 2021; Published: July 13, 2021

*Corresponding author: Khalid Abdel Naser Abdel Rahim, Department of Civil Engineering, Faculty of Science and Technology, University of Coimbra, Rua Luis Reis dos Santos 290, 3030-790 Coimbra, Portugal

Keywords: Composite columns; Lateral impact; FEM modelling; High performance concrete

\section{Introduction}

\section{Principles and Contexts of Composite columns} subjected to lateral impact

Concrete filled steel tube (CFST) column is an important type of structural member and its protective design is essential to enhance its structural performance under various dynamic loads. In accordance to Abdel Rahim [1], the previously carried out studies on CFST columns tried to determine how to improve their structural response under various loadings, such as axial compression, lateral impact, blast, seismic, etc. Apart from investigations on transverse impact loading, the majority of the other studies on CFST under various loads established solutions and protective measures. Therefore, the departure point for this short communication is the need to improve the performance of CFST under transverse impact loads. The study carried out by Zhao et al. [2] shows considerable residual displacement magnitudes after impact. Retaining the geometrical properties, boundary conditions, loading conditions and type of numerical analysis employed in that investigation, this short communication proposes novel designs in terms of cross-sectional configuration and smart materials to be applied on the specimens tested by Wang et al. [3], to improve the performance of CFST columns under lateral impact loading namely reducing their strength degradation under impact, increasing their energy dissipation capacity, reducing the damage to the steel tubes and concrete fill and reducing the residual and maximum displacements.

The proposed investigation is exclusively numerical, and its results could be compared with the experimental results of other authors. The considered three main variables are: a) hollowness ratio,

b) magnitude of axial load and

c) drop weight height.

Several modifications on the previous configurations are proposed and investigated:

a. concrete-filled double skin steel tubular-CFDST,

b. CFDST with first sandwich layer filled with Ultra HighPerformance Fiber-Reinforced Concrete - UHPFRC, (3) CFDST with first sandwich layer filled with UHPFRC and internal carbon steel tube filled with normal strength concrete - NSC,

c. CFDST with first sandwich layer filled with UHPFRC and second sandwich layer filled with NSC,

d. CFDST with first sandwich layer filled with UHPFRC, second sandwich layer filled with NSC and third skin internal tube filled with NSC, and

e. Circular hybrid triple skin stainless steel tubular columns filled with UHPFRC and externally strengthened with GFRP.

The results could be assessed and compared with experimental results in terms of failure modes, dynamic impact force versus time, mid-span deflection versus time, and residual displacements. The major outputs include recommendations on the design of CFST subject to lateral impact and information for an experimental follow up of this numerical investigation 


\section{Civil Engineering Research Journal}

including characterization of the specimens and lab setup. It is strongly believed, that the proposed circular hybrid triple skin stainless steel tubular columns filled with UHPFRC with reference to material properties used by Wang et al. [4] and externally strengthened with GFRP with reference to material properties used by Alam et al. [5] will have a great advantages in this field and will increase the percentage of global impact resistivity and reduce buckling of steel tubes and decreases the maximum and residual displacements under transverse impact conditions.

\section{References}

1. Abdel Rahim KAN (2021) Literature Review: Concrete Filled Steel Tubes Under Transverse Impact Loading, Current Trends in Civil \& Structural Engineering 7(3).
2. Zhao H, Wang R, Hou CC, Lam D (2019) Performance of circular CFDST members with external stainless steel tube under transverse impact loading, Thin-Walled Structures 145: 106380.

3. Wang W, Wu C, Li J, Liu Z, Lv Y (2019) Behavior of ultra-high performance fiber-reinforced concrete (UHPFRC) filled steel tubular members under lateral impact loading, International Journal of Impact Engineering 132: 103314.

4. Wang W, Wu C, Liu Z (2019) Compressive behavior of hybrid doubleskin tubular columns with ultra-high performance fiber-reinforced concrete (UHPFRC). Engineering Structures 180: 419-441.

5. Alam M I, Fawzia S, Zhao X L, Remennikov A M, Bambach M R (2017) Performance and dynamic behaviour of FRP strengthened CFST members subjected to lateral impact, Engineering Structures 147: 160-176.

\section{Your next submission with Juniper Publishers will reach you the below assets}

- Quality Editorial service

- Swift Peer Review

- Reprints availability

- E-prints Service

- Manuscript Podcast for convenient understanding

- Global attainment for your research

- Manuscript accessibility in different formats

( Pdf, E-pub, Full Text, Audio)

- Unceasing customer service

Track the below URL for one-step submission https://juniperpublishers.com/online-submission.php 